\title{
PEMANFAATAN TEPUNG LIMBAH IKAN GABUS PASIR (Butis amboinensis) SEBAGAI SUBSTITUSI TEPUNG IKAN KOMERSIAL DALAM RANSUM TERHADAP FERTILITAS, DAYA TETAS DAN MORTALITAS EMBRIO ITIK LOKAL
}

\section{UTILIZATION OF GABUS PASIR(BUTIS AMBOINENSIS) WASTE FISH MEAL FOR SUBSTITUTION OF COMMERCIAL FISH MEAL IN DIET ON FERTILITY, HATCHABILITY AND EMBRYO MORTALITY OF EGG LAYING DUCK}

\author{
Dian Syahputra $^{1}$, Tri Hesti Wahyuni ${ }^{2}$, R. Edhy Mirwandhono ${ }^{2}$ dan \\ Tati Vidiana Sari ${ }^{2}$ \\ 1. Mahasiswa Program Studi Peternakan Fakultas Pertanian Universitas Sumatera Utara \\ 2. Staf Pengajar Program Studi Peternakan Fakultas Pertanian Universitas Sumatera Utara
}

\begin{abstract}
This research was conducted at Laboratory Animal Biology, Agriculture Faculty, Sumatera Utara University from March to July 2015. This study aimed to determine the effect of gabus pasir waste fish meal (GPWFM) (Butis amboinensi) in diet of laying duck on fertility, hatchability and embryo mortality of duck egg. The design used in this research was completely randomized design $(C R D)$ with 3 treatments and 6 replications. The treatment consisted of level substitution GPWFM by commercial fish meal at ratio 0:10 (P0); 5:5 (P1); and 10:0 (P2). This research used 134 eggs from 52 ducks and 18 drakes. The results showed the average offertility percentage on treatment such as: 97.92; 100 and 100,respectively, hatchability (\%) such as: 76.63; 79.50and 84.17, respectively and embryo mortality (\%) such as:23.37; 20.45 and 15.83, respectively. The results analys showed that the treatments had no significantly on fertility, hatchability and embryo mortality $(P>0,05)$. The conclusion of this research that gabus pasir waste fish meal can substitution of commercial fish meal.
\end{abstract}

Keywords: Gabus pasir waste fish meal, fertility, hatchability and embryo mortality of egg laying duck

\begin{abstract}
ABSTRAK
Penelitian ini dilaksanakan di Laboratorium Biologi Ternak Fakultas Pertanian Universitas Sumatera Utara dari bulan Maret sampai dengan Juli 2015. Penelitian ini bertujuan untuk mengetahui pengaruh pemberian tepung limbah ikan gabus pasir (Butis amboinensis) dalam ransum terhadap fertilitas, daya tetas dan mortalitas embrio itik petelur. Rancangan yang digunakan dalam penelitian ini adalah rancangan acak lengkap (RAL) dengan 3 perlakuan dan 6 ulangan. Perlakuan menggunakan perbandingan tepung limbah ikan gabus pasir dengan tepung ikan komersil antara 0:10 (P0), 5:5 (P1) dan 10:0 (P2). Penelitian ini menggunakan 134 butir telur yang berasal dari 52 ekor betina dan 18 ekor pejantan. Hasil penelitian menunjukan persentase fertilitas secara berturut turut sebesar 97,92; 100 dan 100, daya tetas (\%) 76,63; 79,50 dan 84,17, mortalitas embrio (\%) 23,37; 20,45 dan 15,83. Hasil menunjukan bahwa perlakuan tidak memberikan pengaruh nyata terhadap fertilitas, daya tetas dan mortalitas embrio $(\mathrm{P}>0,05)$. Kesimpulannya adalah bahwa tepung limbah ikan gabus pasir dapat menggantikan tepung ikan komersil.
\end{abstract}

Kata kunci: Tepung Limbah Ikan Gabus Pasir, fertilitas, daya tetas dan mortalitas embrio Itik Petelur 


\section{PENDAHULUAN}

Limbah ikan merupakan limbah yang sudah tidak digunakan lagi atau yang akan dibuang seperti kepala, isi perut dan sisik ikan. Banyak sekali limbah ikan tersebut tersimpan atau dibuang di tempat pelelangan ikan atau di gudang ikan. Limbah perikanan merupakan sisa buangan dari usaha perikanan yang mengalami proses perlakuan atau pengolahan untuk memperoleh hasil utama atau hasil samping.

Bibit ternak itik merupakan masalah bagi peternak terutama dalam hal kualitas dan kuantitasnya. Peternak pada umumnya mengandalkan ternak bibit dari pihak lain (pedagang) itik yang menyediakan bibit dari hasil penetasan telur para pengusaha penetasan. Peternak mulai menyadari akan kualitas maupun kuantitasnya tidak menjamin memenuhi permintaan.

Upaya penyediaan bibit adalah dengan melakukan penetasan. Penetasan telur merupakan suatu proses biologis yang kompleks dari siklus hidup unggas untuk menghasilkan individu baru. Fertilitas telur dipengaruhi berbagai faktor antara lain : pakan, suhu kandang, dan spermatozoa. Selain penanganan telur dan proses penentasan kurangnya asupan nutrisi bagi indukan itik dapat mempengaruhi rendahnya daya tetas dan fertilitas pada itik.

Fertilitas sangat berpengaruh terhadap daya tetas telur karena dengan fertilitas yang baik akan memberikan daya tetas yang tinggi begitu sebaliknya bahwa fertilitas yang rendah akan menghasilkan daya tetas yang rendah. Daya tetas merupakan aspek penting dalam penetasan. Daya tetas yang tinggi akan menghasilkan keuntungan yang tinggi. Mortilitas perlu diperhatikan karena akan menentukan bibit itik yang dihasilkan. Mortilitas berhubungan dengan proses penetasan. Aspek tersebut saling berhubungan untuk menghasilkan itik yang berkualitas dan berkuantitas.

Salah satu faktor penunjang produktifitas itik adalah pakan. Saat ini telah terjadi fluktuasi harga pakan peternakan yang dapat merugikan peternak itu sendiri, sehingga perlu adanya tindakan untuk mengatasi tingginya harga pakan ternak tersebut yaitu dengan menciptakan pakan alternatif dengan memanfaatkan lingkungan sekitar.

Salah satu bahan pakan alternatif yang dapat digunakan sebagai sumber protein dalam ransum dan memberikan peluang yang baik adalah tepung limbah ikan gabus pasir yang berasal dari kepala ikan dan isi perut yang tidak termanfaatkan di tempat pelelangan ikan atau di gudang ikan. Limbah ikan gabus pasir dapat diolah menjadi tepung untuk menjadi substitusi tepung ikan komersil. 


\section{BAHAN DAN METODE}

\section{Tempat dan Waktu Penelitian}

Penelitian di laksanakan di Laboratorium Biologi Ternak Departemen Peternakan Fakultas Pertanian Universitas Sumatera Utara. Penelitian ini berlangsung selama 16 minggu dimulai dari bulan Maret sampai dengan Juli 2015.

\section{Bahan dan Alat Penelitian}

Bahan yang digunakan yaitu itik lokal umur 24 minggu sebanyak 72 ekor betina dan 18 ekor jantan, telur itik sebanyak 134 butir, bahan penyusun ransum terdiri dari jagung, dedak padi, bungkil kelapa, bungkil kedelai, tepung ikan, minyak nabati, bungkil inti sawit, tepung limbah ikan gabus pasir (Butis amboinensis); top mix, air minum memenuhi kebutuhan air dalam tubuh yang diberikan secara ad libitum, air gula untuk mengurangi stress dari kelelahan transportasi, rodalon sebagai desinfektan kandang, formalin dan $\mathrm{KMNO}_{4}$ untuk fumigasi alat penetasan dan mesin tetas dan peralatan tempat pakan dan minum.

Alat yang digunakan adalah kandang model litter sebanyak 18 plot, masing-masing dengan ukuran panjang $80 \mathrm{~cm}$, lebar $70 \mathrm{~cm}$ dan tinggi $50 \mathrm{~cm}$ peralatan kandang terdiri dari 18 unit tempat pakan dan 18 unit tempat minum dan timbangan salter digital kapasitas $5000 \mathrm{~g}$ untuk menimbang berat telur itik dan menimbang ransum, mesin tetas dengan kapasitas 100 butir, alat peneropong telur (candling) termometer sebagai pengukur suhu kandang, hygrometer sebagai alat pengukur kelembaban, jangka sorong. Alat pencatat data seperti buku data, alat tulis dan kalkulator, alat pembersih kandang berupa sapu, ember, sekop dan hand sprayer, alat lain berupa plastik, ember dan pisau.

\section{Metode Penelitian}

Penelitian ini merupakan penelitian eksperimental di bidang Ilmu Produksi Ternak dengan menggunakan Rancangan Acak Lengkap (RAL) Pola searah dengan 3 perlakuan (P0, P1, P2) dan 6 kali ulangan, masing-masing ulangan terdiri dari 5 ekor betina dan 1 ekor pejantan.

Macam perlakuan dalam penelitian ini adalah sebagai berikut:

$\mathrm{P} 0=$ Ransum dengan kandungan tepung ikan gabus pasir $0 \%+100 \%$ tepung ikan komersil

$\mathrm{P} 1=$ Ransum dengan kandungan tepung ikan gabus pasir 50\% $+50 \%$ tepung ikan komersil

P2 $=$ Ransum dengan kandungan tepung ikan gabus pasir 100\% + 0\% tepung ikan komersil 
Lampiran 1. Formulasi Ransum

\begin{tabular}{lccc}
\hline Bahan & P0 & P1 & P2 \\
\hline Tepung Jagung (\%) & 45 & 45 & 45 \\
Tepung Ikan (\%) & 10 & 5 & 0 \\
Bungkil Kedelai (\%) & 7 & 7 & 7 \\
Dedak (\%) & 18 & 18 & 18 \\
Bungkil Inti Sawit (\%) & 14 & 14 & 14 \\
Tepung Limbah Ikan Gabus Pasir(\%) & 0 & 5 & 10 \\
Batu Kapur (\%) & 3 & 3 & 3 \\
M. Nabati (\%) & 3 & 3 & 3 \\
\hline Total & 100 & 100 & 100 \\
\hline Protein (\%) & 15,87 & 16,15 & 16,39 \\
EM (Kkal/g) & 3311,80 & 3223,2 & 3397,7 \\
Serat Kasar (\%) & 5,73 & 5,71 & 5,58 \\
Lemak Kasar (\%) & 5,88 & 5,60 & 5,49 \\
Ca(\%) & 2,04 & 1,94 & 1,85 \\
P(\%) & 1,10 & 0,90 & 0,71 \\
\hline
\end{tabular}

\section{Parameter Penelitian}

\section{Fertilitas Telur}

Nuryati, et al., (2000) menyatakan bahwa fertilitas adalah persentasi telur yang fertile dari sejumlah telur yang digunakan dalam suatu penetasan.

$$
\text { fertilitas }=\frac{\text { Jumlah telur y ang fertil }}{\text { Jumlah telur y ang ditetaskan }} \times 100 \%
$$

\section{Daya Tetas}

Daya tetas adalah hasil telur yang fertil sampai dapat menetas dan dihitung pada akhir penetasan dengan mengetahui persentase daya tetas dengan menggunakan cara menurut Suprijatna, et al., (2008) sebagai berikut:

$$
\text { Dayatetas }=\frac{\text { Jumlah telur y ang menetas }}{\text { Jumlah telur y ang fertil }} \times 100 \%
$$




\section{Mortilitas}

Persentase mortalitas embrio adalah persentase jumlah telur yang tidak menetas dari jumlah telur yang fertil (Rasyaf, 1993).

mortalitas $=\frac{\text { Jumlah telur y ang tidak menetas }}{\text { Jumlah telur y ang fertil }} \times 100 \%$

\section{HASIL DAN PEMBAHASAN}

Hasil nilai rataan terhadap fertilitas, daya tetas, dan mortalitas embrio itik lokal dapat dilihat pada Tabel 2 di bawah ini.

Tabel 2. Rataan fertilitas, daya tetas, dan mortalitas embrio Itik Lokal

\begin{tabular}{lccc}
\hline \multicolumn{1}{c}{ Peubah } & \multicolumn{3}{c}{ Perlakuan } \\
\cline { 2 - 4 } & P0 & P1 & P2 \\
\hline Fertilitas (\%) & $97,92^{\text {tn }} \pm 5.10$ & $100,00^{\mathrm{tn}} \pm 0,00$ & $100,00^{\mathrm{tn}} \pm 0,00$ \\
Daya tetas (\%) & $76,63^{\mathrm{tn}} \pm 8,99$ & $79,50^{\mathrm{tn}} \pm 8,62$ & $84,17^{\mathrm{tn}} \pm 9,12$ \\
Mortalitas embrio (\%) & $23,37^{\mathrm{tn}} \pm 8,98$ & $20,50^{\mathrm{tn}} \pm 8,66$ & $15,83^{\mathrm{tn}} \pm 9,12$ \\
\hline
\end{tabular}

Keterangan: tn $=$ tidak nyata

\section{Fertilitas}

Fertilitas adalah persentase telur fertil dari sejumlah telur yang digunakan dalam suatu penetasan. Untuk mengetahui fertil atau tidak fertilnya telur yaitu setelah 7 hari telur dalam mesin tetas, dilakukan Candling (peneropongan telur) untuk mengetahui telur yang dibuahi dengan telur yang tidak dibuahi

Berdasarkan Tabel 2 dapat diketahui bahwa rataan fertilitas yang tertinggi terdapat pada perlakuan P1 dan P2 yaitu sebesar $100 \%$ dan terendah terdapat pada P0 $(97,92 \%)$. Walaupun terlihat ada kecenderungan bahwa perlakuan penggunaan tepung limbah ikan gabus pasir sebanyak 10\% (P2) dalam ransum menghasilkan persentase fertilitas telur yang lebih tinggi dari pada perlakuan yang menggunakan tepung ikan komersil 10\% (P0) namun perbedaan tersebut secara uji statistik tidak nyata $(\mathrm{P}>0,05)$. Hal ini berarti pemberian tepung limbah ikan gabus pasir dalam ransum dapat menggantikan tepung ikan komersil secara keseluruhan.

Hasil analisis ragam menunjukkan bahwa pengaruh pemberian tepung limbah ikan gabus pasir dalam ransum tidak berbeda nyata $(\mathrm{P}>0,05)$ terhadap fertilitas. Tidak adanya pengaruh yang nyata terhadap fertilitas antar perlakuan dipengaruhi oleh kandungan nutrisi ransum yang hampir sama pada tiap perlakuan. Hal ini menunjukkan bahwa ransum 
pemberian tepung ikan mempunyai kandungan nutrisi yang sama baiknya dengan ransum pemberian tepung limbah ikan gabus pasir. Hal tersebut dibuktikan dengan kandungan mineral (kadar abu) dalam tepung ikan berkisar 5,2\% dan kandungan mineral tepung limbah ikan gabus pasir sebesar 5,86\% Suprijatna, et al. (2005) menyatakan bahwa mineral utama yang terlibat dalam proses embrional yaitu kalsium. Pada telur infertil tidak terjadi peningkatan kadar kalsium selama periode penetasan. Apabila pakan induk defesiensi akan mineral maka berdampak pada fertilitas dari telur yang ditetaskan, hal ini juga berpengaruh pada pembentukan embrional.

Hasil rataan fertilitas antara 97,92\% hingga 100\%. Hasil ini lebih tinggi dari penelitian sebelumnya yang dilaksanakan oleh wati (2014) dengan rerata fertilitas berkisar $72 \%-90 \%$. Lebih tinginya penelitian ini dikarenakan dalam penelitian menggunakan ransum yang sesuai dengan kebutuhan ternak, sedangkan penelitian dilakukan wati terjadi penambahan dedak poles dan kupang pada pakan konsentratnya sehingga kandungan nutrisi yang di konsumsi oleh ternak tidak sesuai dengan kebutuhan ternak tersebut.

\section{Daya Tetas}

Daya tetas merupakan persentase telur yang menetas dari total telur fertil. Daya tetas berdasarkan perlakuan penggunaan tepung limbah ikan gabus pasir dari tingkat berbagai level dapat dilihat pada Tabel 2. Berdasarkan Tabel 2 dapat diketahui bahwa rataan daya tetas yang tertinggi terdapat pada perlakuan P2 sebesar 84,17, P1 sebesar 79,50 dan terendah terdapat pada P0 sebesar 76,63. Adapun perbedaan yang tampak pada rataan daya tetas telur itik lokal dari hasil penelitian tetapi secara statistik menunjukkan tidak berbeda nyata $(\mathrm{P}>0.05)$. Hal ini berarti penggunaan tepung limbah ikan gabus pasir sampai taraf $10 \%$ dalam ransum dapat mensubtitusi penggunaan tepung ikan komersil.

Berdasarkan Tabel 2 diketahui bahwa pemberian tepung ikan gabus pasir dalam ransum memberikan pengaruh yang sama. Hal ini dikarenakan pemberian tepung limbah ikan gabus pasir memiliki kandungan lipid yang dapat memenuhi kebutuhan perkembangan emrbional yaitu 4,32 dan tepung ikan komersil yaitu 6,49 yang berpengaruh terhadap daya tetas telur. Dalam penyusunan ransum formula untuk pakan induk, lipid merupakan komponen yang sangat menentukan bagi fungsi reproduksi dari induk betina, demikian pula perkembangan embrio serta kelangsungan hidup pada saat penyerapan kuning telur (Mazorra et al., 2003). Lipida yang dimaksud di atas terutama golongan PUFA. Seperti elcosapentaenoic acid (20:5 n-3; EPA) dan docosahexaenoic acid (22:6 n-3; DHA). ( Watanabe \& Vassallo-Agius, 2003). 
Hasil rataan daya tetas antara 76,63\% hingga $84,17 \%$. Hasil ini lebih tinggi dari penelitian sebelumnya yang dilaksanakan oleh Derwanti (2014) dengan rerata daya tetas berkisar 73,64\%-83,28\%. Lebih tinginya penelitian ini dikarenakan dalam penelitian telur yang digunakanhanya berumur satu hari sebelum ditetaskandan menggunakan mesin tetas automatis dengan harapan persentase daya tetas yang dihasilkan lebih tinggi.

\section{Mortalitas}

Persentase mortalitas embrio adalah persentase jumlah telur yang tidak menetas dari jumlah telur yang fertil (Rasyaf, 1993). Berdasarkan Tabel 2 dapat diketahui bahwa rataan mortalitas yang tertinggi terdapat pada perlakuan P0 sebesar 23,37 P2 sebesar 22,57dan terendah terdapat pada P2 sebesar 15.83. Tidak adanya perbedaan padarataan mortalitas dari hasil penelitian secara uji statistic menunjukan tidak berbeda nyata $(\mathrm{P}>0,05)$. Hal ini berarti penggunaan tepung limbah ikan gabus pasir sampai taraf $10 \%$ dalam ransum dapat menggantikan penggunaan tepung ikan komersil.

Rendahnya kematian embrio yang terjadi pada penelitian ini disebabkan daya tetas yang cukup tinggi hingga mencapai 84,17.\%.Daya tetas adalah hasil telur yang fertil sampai dapat menetas dan dihitung pada akhir penetasan dengan mengetahui persentase daya tetas dengan menggunakan cara menurut Suprijatna, et al., (2008) ini menunjukkan bahwa mortalitas berbanding terbalik dengan daya tetas, rendahnya mortalitas pada penelitian ini disebabkan karena nutrisi pada ikan gabus pasir tidak jauh berbeda dengan tepung ikan komersil, sehingga pengeruh terhadap mortalitas tidak jauh berbeda.

\section{KESIMPULAN}

Tepung limbah ikan gabus pasir dapat digunakan sebagai bahan pakan itik petelur fase bertelur hingga level $10 \%$ dan dapat menggantikan penggunaan tepung ikan komersil sebagai campuran dalam pembuatan ransum.Pemanfaatan tepung limbah ikan gabus pasir dalam ransum untuk peternak itik petelur pada fase bertelur disarankan pada level $10 \%$.

\section{DAFTARPUSTAKA}

Derwanti et al., 2014.Pengaruh Bobot Dan Frekuensi Pemutaran Telur Terhadap Fertilitas, Daya Tetas, Dan Bobot Tetas Itik Lokal. Skripsi. Jurusan Peternakan Fakultas Pertanian Universitas Sebelas Maret, Surakarta

Mazzora, C., Bruce M., Bell J. G., Davie A., Alorend E., Jordan, N., Ress J., Papanikos N., Porter M. and Bromage N., 2003. Dieary Lipid Enhancement Of Broodstock Reproductive Performance And Egg And Larval Quality In Atlantic Halibut (Hippoglossus Hippoglossus). Aquaculture, 227, 21-23 
Nuryati, L, Sutarto, K, dan Harfjosworo,S.P.,2000. Sukses Menetaskan Telur, Penebar Swadaya, Jakarta.

Rasyaf, M. 1993. Mengelola Itik Komersial. Kanisius. Yogyakarta.

Suprijatna, E. U. Atmomarsono dan R. Kartasudjana. 2005. Ilmu Dasar Ternak Unggas. Penebar Swadaya, Jakarta

Suprijatna, E. U. Atmomarsono dan R. Kartasudjana. 2008. Ilmu Dasar Ternak Unggas. Cetakan ke-2. Penebar Swadaya, Jakarta

Watanabe, t., 2003. Importance Of Docosahexaenoic acid in Marine Larval Fish. Journal Of the world aquaculture, 227, 35-61

Wati Y. 2014. Pengaruh Tepung Kulit Mangis Terhadap Tinggi Fertilitas, Daya Tetas Dan Bobot Tetas Itik Mojosari. Fakultas Peternakan Universitas Brawijaya. Malang 